\title{
First record of the exotic species Hemiculter leucisculus (Pisces: Cyprinidae) in southern Iran
}

\author{
Alireza Radkhah ${ }^{1}$, Soheil Eagderi ${ }^{1, *}$ and Hamed Mousavi-Sabet ${ }^{2}$ \\ ${ }^{1}$ Department of Fisheries, Faculty of Natural Resources, University of Tehran, Karaj, Iran. \\ ${ }^{2}$ Department of Fisheries, Faculty of Natural Resources, University of Guilan, Sowmeh Sara, P.O. Box: 1144, \\ Guilan, Iran. \\ *Corresponding author: soheil.eagderi@ut.ac.ir
}

Received: $10 / 02 / 2015 \quad$ Accepted: 13/10/2015

\begin{abstract}
First record of the exotic Hemiculter leucisculus (Pisces, Cyprinidae) in southern Iran

The occurrence of the sawbelly, Hemiculter leucisculus, is reported for the first time from the Halil River in the Hamun-eJazmourian basin, Kerman Province, southern Iran. The sawbelly is an exotic species in Iran. This species may have adverse effects on native fishes, as the sawbelly is an aggressive and territorial species that is well-known for its ability to rapidly colonize a body of water. This new data regarding its range demonstrates an extension of this species' known range further to the southern area of Iran.
\end{abstract}

Key words: Sawbelly, Halil river, Kerman Province, Exotic species.

\section{RESUMEN}

Primer registro del pez exótico "Sawbelly" Hemiculter leucisculus (Pisces, Cyprinidae) en el sur de Irán

La presencia de Hemiculter leucisculus se reporta por primera vez en el río Halil en la cuenca Hamun-e-Jazmourian, provincia de Kermen al sur de Irán. Esta especie es exótica en Irán. La presencia de Hemiculter leucisculus tiene efectos negativos en las especies nativas, ya que es una especie agresiva y territorial y es bien conocida por su facilidad para colonizar rápidamente un nuevo hábitat. Esta nueva información demuestra una extensión en su rango de distribución hacia el sur de Irán.

Palabras clave: "Sawbelly", río Halil, provincia de Kerman, especies exóticas.

\section{INTRODUCTION}

The sawbelly, Hemiculter leucisculus, is a freshwater and brackish water fish belonging to the Cultrinae subfamily (Cyprinidae) (Abdoli, 2000). This is a widespread species, occurring in heavily-modified water bodies (Coad, 2014). Hemiculter leucisculus is usually found in shallow water over a sandy bottom of large and medium-sized rivers (Coad, 2014); however, occasionally they are found in pools along the beds of mountain streams (Patimar et al., 2008) and in ponds, lakes and the backwaters of rivers (Coad, 2014). This species is highly tolerant of water pollution (Coad, 2014). It is native to the rivers of China, Korea and Vietnam and to the Amur River basin (Holčík \& Razavi, 1992). Hemiculter leucisculus was reported from different Iranian inland water resources, including Zarivar Lake (Esmaeili et al., 2011), the Sefidrud and Aras Rivers, and the Anzali, Alma-Gol, Adji-Gol and Ala-Gol wetlands (Mousavi-Sabet 
et al., 2013). It also occurs in the Hari River in Turkmenistan and therefore may be found in the Hari River basin of Iran (Coad, 2014; Esmaeili et al., 2011). This species has now been found in the Halil River in the Hamun-e-Jazmourian basin, demonstrating an extension of its known range to the southern area of Iran.

\section{MATERIALS AND METHODS}

Eighteen sawbelly specimens were caught in the Halil River near Jiroft city, Kerman Province

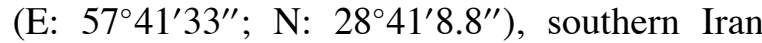
(Fig. 1), on 5 August 2014 using a backpack electrofishing equipment (SAMUS-725M; Poland). Fish samples were fixed in $10 \%$ buffered formaldehyde. A total of 20 morphometric characters were measured using a digital caliper to the nearest $0.1 \mathrm{~mm}$ (Table 1). Methods for taking counts and measurements follow Hubbs \& Lagler (1958).

\section{RESULTS}

The eighteen collected specimens of H. leucisculus from the Halil River range from 96 to 121 $\mathrm{mm}$ in standard length (Fig. 1). The general body shape of the collected H. leucisculus is displayed
Table 1. Morphometric characteristics (Mean \pm SD) of Hemiculter leucisculus collected from the Halil River $(\mathrm{SD}=$ standard deviation; Min = minimum; Max = maximum; number of specimens $=18)$. Características morfométricas $(\mathrm{Me}$ dia $\pm S D)$ de Hemiculter leucisculus en el río Halil $(S D=$ desviación estandar $;$ Min = mínimo $;$ Max = máximo $;$ número de especímenes $=18$ ).

\begin{tabular}{|c|c|c|}
\hline Characters & Mean \pm SD & Min-Max \\
\hline Total length (mm) & $125.39 \pm 10.04$ & $111-140$ \\
\hline Standard length (mm) & $106.89 \pm 8.18$ & $95-121$ \\
\hline \multicolumn{3}{|l|}{ Standard length \% } \\
\hline Total length & $117.30 \pm 2.75$ & $112.61-123.01$ \\
\hline Body depth & $23.34 \pm 1.25$ & $21.70-26.32$ \\
\hline Predorsal length & $52.82 \pm 1.67$ & $50.50-56.64$ \\
\hline Prepelvic length & $49.23 \pm 2.00$ & $46.88-54.87$ \\
\hline Preanal length & $71.91 \pm 1.76$ & $69.57-76.99$ \\
\hline Dorsal-fin height & $14.84 \pm 1.57$ & $11.57-17.65$ \\
\hline Dorsal-fin base length & $11.09 \pm 0.79$ & $9.92-12.62$ \\
\hline Anal-fin height & $10.24 \pm 1.32$ & $8.26-13.21$ \\
\hline Anal-fin base length & $12.43 \pm 1.08$ & $10.62-14.58$ \\
\hline Ventral-fin length & $12.53 \pm 1.33$ & $9.92-14.71$ \\
\hline Pectoral-fin length & $16.91 \pm 2.24$ & $12.87-20.00$ \\
\hline pectoral - pelvic fins distance & $28.19 \pm 1.31$ & $25.47-30.69$ \\
\hline Caudal peduncle $\mathrm{L}$ & $17.25 \pm 1.08$ & $15.69-19.81$ \\
\hline Caudal peduncle $\mathrm{D}$ & $9.59 \pm 0.73$ & $8.40-10.78$ \\
\hline Head width & $17.31 \pm 0.98$ & $15.52-19.47$ \\
\hline Head length & $19.99 \pm 2.48$ & $16.83-26.55$ \\
\hline \multicolumn{3}{|l|}{ Head length $\%$} \\
\hline Snout length & $19.73 \pm 3.75$ & $10.53-26.67$ \\
\hline Postorbital length & $53.36 \pm 3.72$ & $47.83-60.00$ \\
\hline Eye diameter & $23.52 \pm 3.04$ & $17.65-29.41$ \\
\hline
\end{tabular}

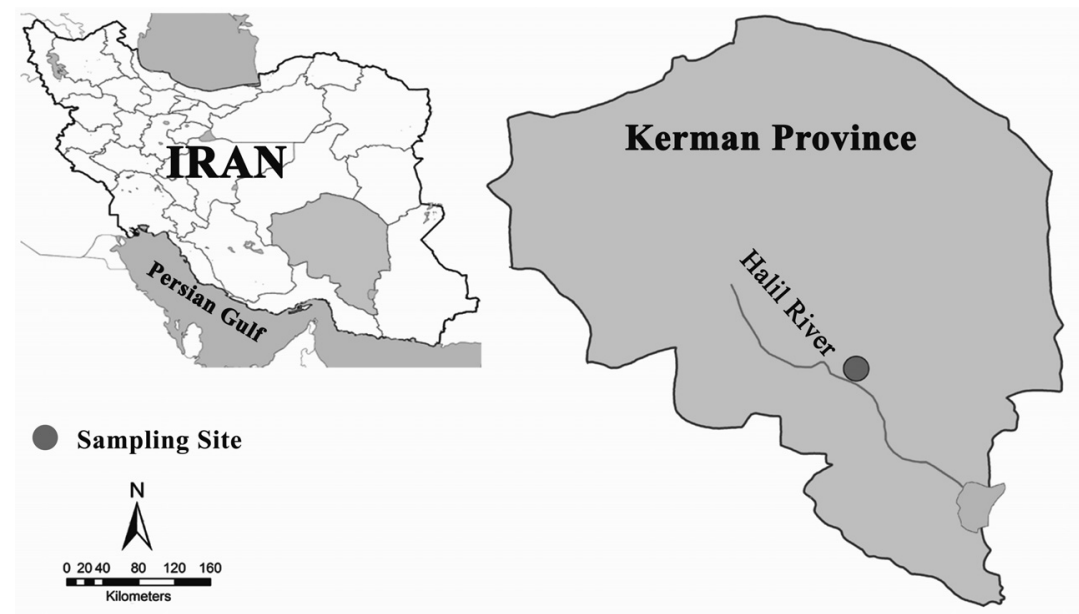

Figure 1. Map of the sampling site in the Halil River, in the Hamun-e-Jazmourian basin, southern Iran. Mapa del lugar de estudio en el río Halil en la cuenca Hamun-e-Jazmourian, en el sur de Irán. 
in Fig. 2. The meristic counts of the preserved specimens are as follows: Dorsal fin: II 7, anal fin: II 12, and 44-59 lateral line scales. The percentage ratios of morphometric characters in relation to standard lengths and head lengths were analyzed and are presented in Table 1.

Two other exotic fish species, Pseudorasbora parva and Carassius auratus, were collected from this river during sampling. Additionally, Macrobrachium nipponense (Oriental River Prawn) was another invasive species collected.

\section{DISCUSSION}

Fish are one of the aquatic taxa that have been widely introduced and translocated. The introduction of a non-native species to an ecosystem likely presents an ecological risk if the species is able to integrate itself successfully into the ecosystem (Gozlan \& Newton, 2009), resulting in possible detrimental interactions with native species or even with the function of the ecosystem (Gozlan et al., 2010). Introduced fish species can play a role in the spread of disease or parasites to other animals. As many parasites have been reported to originate from invasive and native fish species in Iran (Coad, 2014), it seems that the wide distribution of exotic species may have a significant role in the spread of parasites (Esmaeili et al., 2014).

Exotic species were primarily introduced into ecosystems in Iran through human activity, either intentionally or unintentionally (Esmaeili et al.,
2007; 2010). The sawbelly, an exotic species in Iran, is native to Maritime Russia south through China to Korea and Vietnam (Coad, 2014). This species was first reported in the Anzali Wetland by Holčík \& Razavi (1992) and apparently is a common species in that region (Coad, 2014). This species has been introduced to Iran, most likely accidentally along with commercial shipments of Chinese major carp from Central Asia in the former U.S.S.R. and/or Romania in 1967 (Coad, 2014). The Chinese major carp in Central Asia came from the Amur River basin in the Far East, and sawbellies were accidentally transferred with them in 1950-1960 (Holčík \& Razavi, 1992; Coad, 1996). In this study, the sawbelly is reported for the first time in the Halil River in the Hamun-e-Jazmourian basin, Kerman Province, southern Iran. This species was most likely introduced to this river by fish farmers along with other farmed fish, such as Chinese carp.

The sowbelly is able to easily switch from one food to another as conditions change (Holčík \& Razavi, 1992; Coad, 2014) and then is probably compete with native species for food. The preferred habitat of this species are lakes, ponds, and backwaters of rivers; the lower reaches of slow flowing large and medium-sized rivers, shallow water over sandy bottom rivers (Zareian et al., 2015), which makes the Halil River system ideal. This species is known to show more rapid growth rate and a higher fecundity in its preferred habitats than under native conditions (Esmaeili et al., 2010; Zareian et al.,

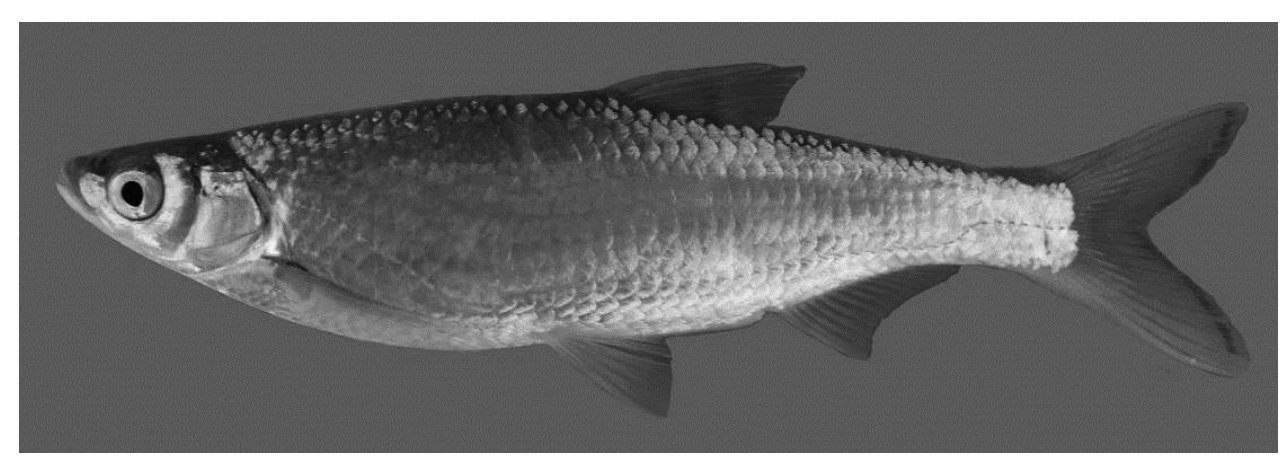

Figure 2. Picture of Hemiculter leucisculus collected from the Halil River, in the Hamun-e-Jazmourian basin, southern Iran. Fotografía de Hemiculter leucisculus muestreado en el río Halil en la cuenca Hamun-e-Jazmourian, en el sur de Irán. 
2015). Contreras \& Escalante (1984) regarded this species as a pest when introduced (Coad, 1996; Coad, 2014). Adaptability to variable environmental conditions allows the sawbelly to breed and become established in areas outside their native range (Martin et al., 2010). These factors may further contribute to the successful reproduction and establishment of this exotic fish in the Hamun-e-Jazmourian basin in the near future. In this study, meristic and morphometric characteristics of the collected specimens were in the range of those reported by Coad (2014) and Abdoli (2000). Monitoring of this newly introduced fish by scientists, conservationists, and environmentalists is highly recommended.

\section{REFERENCES}

ABDOLI, A. 2000. The inland water fishes of Iran. Iranian Museum of Nature and Wildlife, Tehran.

CONTRERAS, S. \& M. A. ESCALANTE. 1984. Distribution and known impacts of exotic fishes in Mexico. In: Distribution, biology, and management of exotic fishes, edited by W. R. Courtenay Jr. and J. R. Stauffer Jr. Baltimore, Johns Hopkins University Press, pp. 102-30

COAD, B. W. 1996. Exotic and transplanted fishes in Southwest Asia. Publicaciones Especiales. Instituto Español de Oceanografía, 21: 81-106.

COAD, B. W. 2014. Freshwater Fishes of Iran. www. briancoad.com.

ESMAEILI, H. R., A. TEIMORI \& G. GHOLAMHOSSEINI. 2007. Freshwater Ichthyodiversity and its conservation in Iran. Xii European Congress on Ichthyology. Cavata (Dubrovnik), Croatia, pp. 200-201.

ESMAEILI, H. R., A. GHOLAMIFARD, A. TEIMORI, S. BAGH-BANI \& B. W. COAD. 2010. Xiphophorus hellerii Heckel, 1848 (Cyprinodontiformes, Poeciliidae), a newly introduced fish recorded from natural freshwaters of Iran. Journal of Applied Ichthyology, 26: 937-938.

ESMAEILI, H. R., A. GHOLAMIFAR \& J. FREYHOF. 2011. Ichthyofauna of Zarivar Lake (Iran) with the first records of Hemiculter leucisculus and Alburnus hohenackeri in the Tigris drainage. Electronic Journal of Ichthyology, 7(1): 1-6.

ESMAEILI, H. R., A. TEIMORI, F. OWFI, K. ABBASI \& B. W. COAD. 2014. Alien and invasive freshwater fish species in Iran: Diversity, environmental impacts and management. Journal of Iranian Society of Ichthyology, 1(2): 61-72.

GOZLAN, R. E. \& A. C. NEWTON. 2009. Biological invasions: benefits versus risks. Science, 324: 1015-1016.

GOZLAN, R. E., J. R. BRITTON, I. COWX \& G. H. COPP. 2010. Current knowledge on non-native freshwater fish introductions. Journal of Fish Biology, 76: 751-786.

HOLČÍK, J. \& V. A. RAZAVI. 1992. On some new or little known freshwater fishes from the Iranian coast of Caspian Sea. Folia Zoologica, 41(3): 271280.

HUBBS, C. L. \& K. F. LAGLER. 1958. Fishes of the Great Lakes Region. University of Michigan Press, Ann Arbor, USA.

MARTIN, C. W., M. M. VALENTINE \& F. J. VALENTINE. 2010. Competitive interactions between invasive Nile tilapia and native fish: the potential for altered trophic exchange and modification of food webs. Plos One, 5: 1-6.

MOUSAVI-SABE, H., A. HABIBI \& O. BAGHERPUR. 2013. Studies on Length-weight and Lengthlength Relationships, Relative Condition Factor and Fulton's Condition Factor of Hemiculter leucisculus (Pisces: Cyprinidae) from the Southwestern Caspian Sea Basin. Our Nature, 11(1): 25-30.

PATIMAR, R., A. ABDOLI \& B. H. KIABI. 2008. Biological characteristics of the introduced Sawbelly, Hemiculter leucisculus (Basilewski, 1855), in three wetlands of northern Iran: Alma- Gol, Adji-Gol and Ala-Gol. Journal of Applied Ichthyology, 24(5): 617-620.

ZAREIAN, H., H. R ESMAEILI., ZAMANIAN NEJAD R., S. VATANDOUST. 2015. Hemiculter leucisculus (Basilewsky, 1855) and Alburnus caeruleus Heckel, 1843: new data on their distributions in Iran. Caspian Journal of Environmental Science, 13(1): 11-20. 